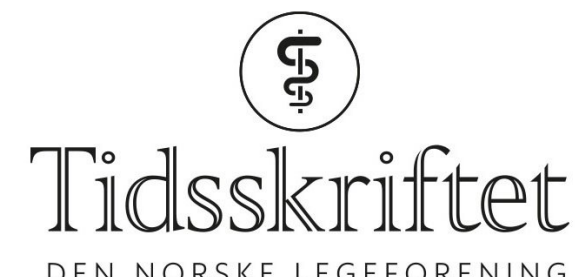

DEN NORSKE LEGEFORENING

\title{
Gleden ved å føle seg nyttig
}

INTERVJU

JANNIKE REYMERT

E-post: jannike.reymert@gmail.com

Tor Åm er på tampen av yrkeskarrieren, men stråler av entusiasme i sin nye jobb som administrerende direktør i Helse Nord-Trøndelag. - Her kommer alt jeg har lært og erfart gjennom et langt liv til nytte!

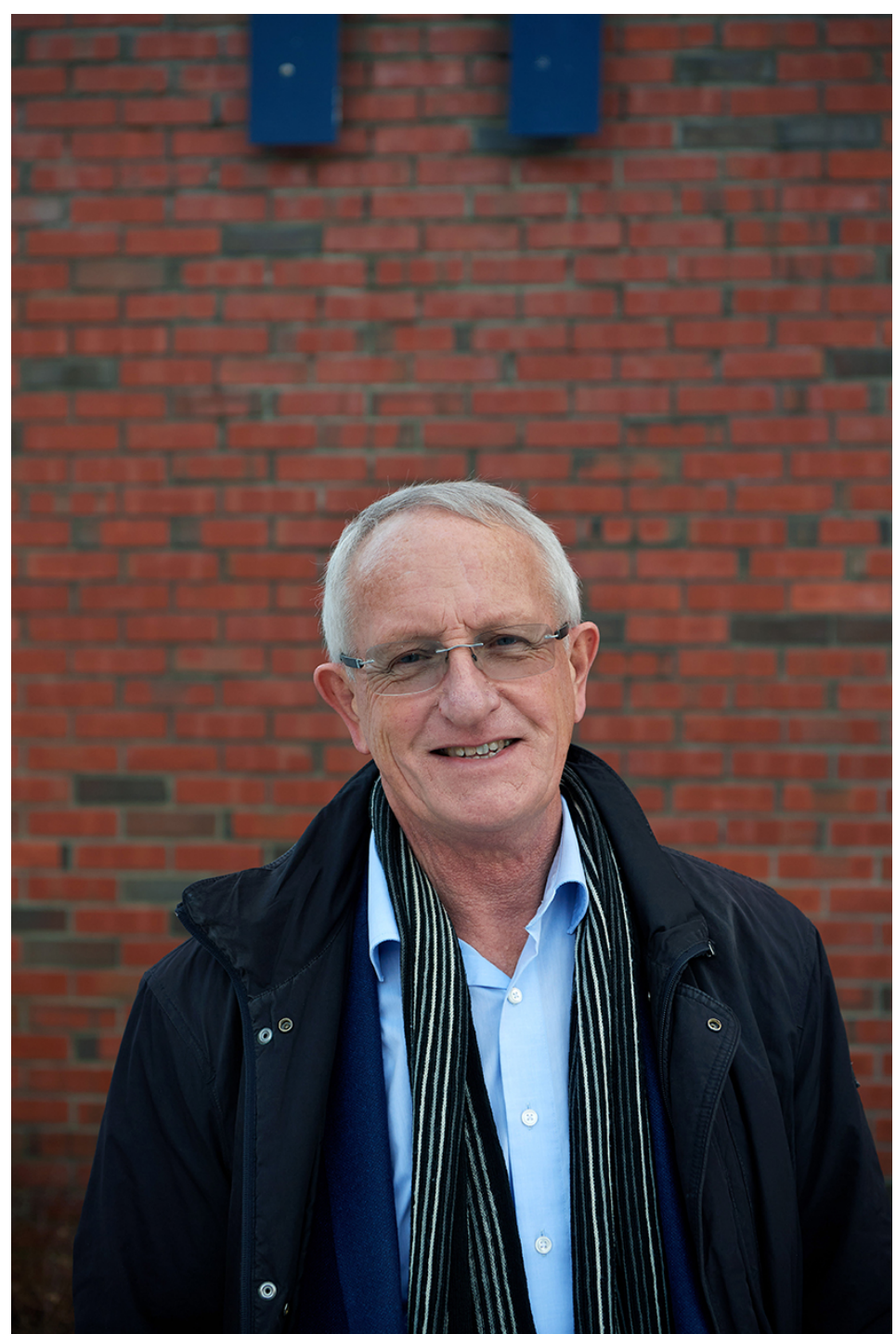

Foto: Bjørn Tore Ncess 
De siste årene har utfordringene i Helse Nord-Trøndelag vært store - både med hensyn til $\emptyset$ konomistyring, samarbeid mellom ledelse og ansatte, og samarbeid internt mellom sykehusene i Namsos og på Levanger. Det ser ut som helseforetaket skjøt gullfuglen etter at den godt voksne trondheimslegen Tor Åm høsten 2019 sa ja til å bidra i et halvt års tid inntil direktørstillingen ble besatt. Han visste av erfaring fra flere år med dag- og ukependling til Oslo hvor slitsomt det er å reise mye, men lot seg likevel friste. Da direktørstillingen ble utlyst, var alle betenkeligheter forsvunnet som dugg for solen. Han søkte og fikk stillingen på permanent basis.

- Jeg ble tatt imot med åpne armer og opplevde raskt at jeg hadde mye å bidra med. Ønsket om å være med på gjennomføringen av ting jeg hadde startet opp, gjorde at jeg valgte å søke jobben. Så lenge helsa holder og jeg fortsatt synes det er gøy, vil jeg stå i jobben, i alle fall til jeg er 72, sier han, og legger til at kona, som er bioingeniør på St. Olavs hospital, ennå har mange år igjen til pensjonsalder.

- Og da haster det ikke for meg å bli pensjonist.

- Hva er drivkraften din for å gå inn i en så krevende stilling når andre på samme alder for lengst har gått over i pensjonistenes rekker?

- For meg handler det om å føle seg nyttig, føle at jeg kan bidra med erfaringer fra et langt yrkesliv. Jeg har brukt mye tid på å få folk til å jobbe bedre sammen i og på tvers av organisasjoner. Det gjelder å bygge en kultur stein på stein ved å være tydelig på hvordan ting bør være, og like tydelig på hva som er uakseptabelt når jeg opplever at vi snakker eller bryter hverandre ned.

Et annet mantra han har, er at de som skal samarbeide, må møtes jevnlig for å bli kjent, bygge gjensidig respekt og derved også klare å løse felles utfordringer sammen. Dette kan gjelde mellom kolleger, men også mellom ledelse og representanter fra ansatte.

Jeg er nok ikke født sånn, jeg er blitt sånn!

- Har du alltid likt å være leder?

- Nei, sier han kontant.

- Min vei inn i ledelse startet med tunge og vonde erfaringer som far til et barn med en alvorlig funksjonshemning. Selv om jeg da var spesialist i allmennmedisin og burde kjenne de ulike tilbudene i vår fantastiske velferdsstat, opplevde jeg at det var vanskelig å finne fram, og at nødvendige tilbud i veldig liten grad var koordinert. Vi var avhengige av kunnskap fra andre pårørende for å finne fram i systemene.

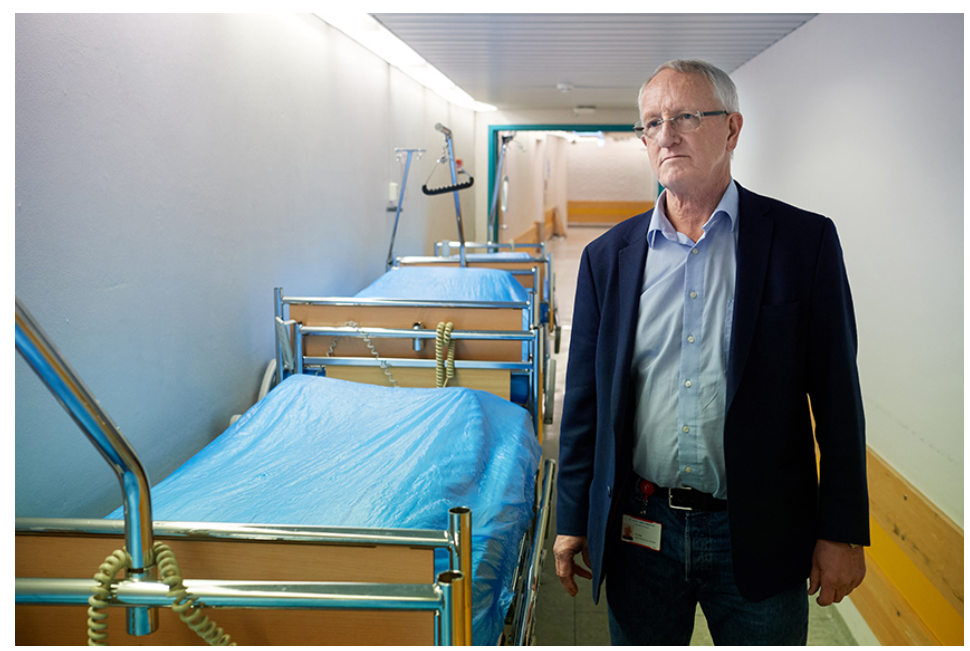

Foto: Bjørn Tore Neess

Denne erfaringen gjorde at han ble opptatt av hvordan han gjennom jobben kunne påvirke systemet til det bedre.

- Dette engasjementet har vært førende for min karriere. Jeg ble etter hvert spesialist i 
samfunnsmedisin, var assisterende fylkeslege en kort periode og fikk i 1989 stilling ved Helsekontoret i Trondheim kommune, hvor jeg skulle arbeide med reformen for utviklingshemmede.

Etter en stund ble han bedt om å delta i et lederutviklingsprogram.

- Det har jeg hatt mye glede av siden. Jeg skjønte at jeg må våge å ta ledelse om jeg skal påvirke på systemnivå. Så jeg er nok ikke født sånn, jeg er blitt sånn!

\section{Når noe går alvorlig galt}

De aller fleste pasienter får gode og nødvendige undersøkelser og behandling i helsevesenet for skade eller sykdom, og er fornøyde med tilbudene de får. Men noen ganger går det galt, av og til går det fryktelig galt. Hva gjør vi da? Og hva gjør vi for å unngå at slike tragedier skjer igjen? Dette er spørsmål som Tor Åm har brukt mye tid og energi på i sin nye stilling.

\section{Tor Åm}

Født 1951

1977 Medisinsk embetseksamen, Universitetet i Bergen

1982-97 Spesialistgodkjenning i allmennmedisin

1990 Juridisk spesialfagseksamen (5. avdeling) i sosialrett/helserett/trygderett, Universitetet

i Oslo

1992 Spesialistgodkjenning i samfunnsmedisin

1998 Mastergrad i helseledelse, Universitetet i Oslo

1979-2020 Vakter ved legevakta i Trondheim

1980-88 Allmennpraksis ved Saupstad legesenter, Trondheim

1988-89 Assisterende fylkeslege i Sør-Trøndelag, vikariat

1990-2009 Ulike lederstillinger i Trondheim kommune

2009-10 Prosjektdirektør, Samhandlingsavdelingen, Helse- og omsorgsdepartementet

2010-11 Kst. ekspedisjonssjef, Samhandlingsavdelingen, Helse- og omsorgsdepartementet

2012-19 Samhandlingsdirektør og fagdirektør for rus og psykisk helse, St. Olavs hospital

2019- d.d. Administrerende direktør, Helse Nord-Trøndelag

Sykehusene i Helse Nord-Trøndelag har de siste to årene hatt to tragiske hendelser med dødelig utgang der diagnostikken har sviktet grovt, og fortvilte pårørende ikke har fått god nok informasjon og oppfølging underveis og i ettertid. Helseforetaket har fått kraftig kritikk både fra tilsynsmyndighetene og pårørende.

- Det var viktig for meg å møte pårørende personlig og lytte til deres opplevelser. Skadene som har skjedd, kan ikke gjenopprettes. Men begge pårørendegruppene er opptatt av at vi, og helsevesenet generelt, må lære av det som har skjedd. Gjennom sin kritikk har de bidratt til at alle vi som arbeider i sykehusene, lettere kan forstå hvordan vi ikke skal opptre, og hvordan manglende oppfølging oppleves. De har lært oss hvordan det oppleves ikke å bli møtt med ydmykhet og forståelse.

Sakene har berørt ham så sterkt at han skrev en kronikk i lokalavisene der han kom med en uforbeholden unnskyldning og betonte at folk skal være trygge på at sykehusene takket være pårørendes åpenhet har fått en unik mulighet til å lære av hendelsene og endre prosedyrer der de har sviktet.

Vi ønsker kritikk når vi har gjort noe som oppleves feil

- Som lege med et langt liv i helsetjenesten vet jeg at vi må møte pasienter og pårørende med respekt og ydmykhet, ikke bare fordi vi skal være høflige, men fordi en slik holdning er nødvendig for at vi skal forstå pasienten, og derved kunne stille rett diagnose og gi rett behandling. En slik holdning er også viktig for å vise at vi ønsker kritikk når vi har gjort noe 
som oppleves feil. Vi som helsepersonell kan ikke selv vurdere hvordan vi virker på våre pasienter og deres pårørende. Derfor må vi aktivt etterspørre pasienters og pårørendes opplevelser av møtene med oss. Dette er viktig i vårt forbedringsarbeid.

Han oppsummerer læringspunktene de har trukket ut av disse sakene, og teller på fingrene mens han ramser dem opp:

- Pasienter og pårørende skal oppleve at de blir tatt på alvor, og at vi bryr oss om dem. Vi skal møte pasienter og pårørende med respekt og ydmykhet og prioritere dialogen med pasienter og pårørende. Det er viktig å knytte kontakt raskt etter en hendelse - og når vi har gjort feil, må vi beklage på en ordentlig og troverdig måte. Så må involverte ansatte ivaretas og følges opp på en trygg og konstruktiv måte. Uønskede hendelser skal benyttes til læring, forbedring og kulturbygging, og prosedyrer og rutiner skal oppdateres og forbedres når det er nødvendig.

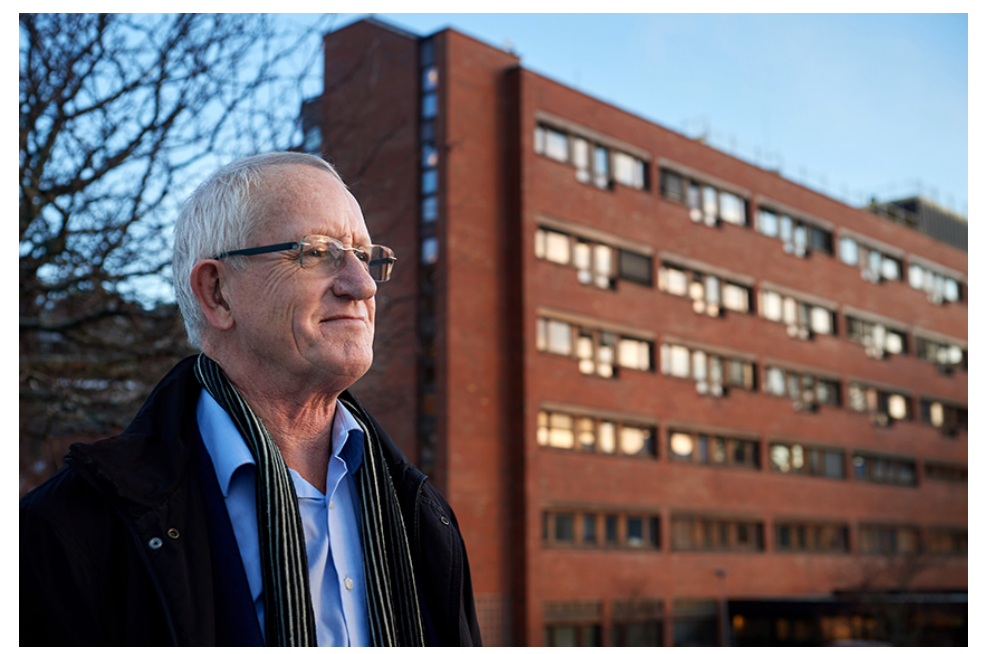

Foto: Bjørn Tore Ncess

\section{Legevakter som hobby}

Som om ikke hans lange karriere i byråkratiet har vært krevende nok, har han hele yrkeslivet valgt å ta legevakter på si.

- Jeg har stort sett hatt én til to vakter i måneden i alle år etter at jeg gikk ut av allmennpraksis. Legevakt gir et fantastisk overblikk over hvordan velferdsstaten fungerer. Du får innblikk i barnevern, eldreomsorg, psykiatri, somatikk og rusomsorg. Du møter pasienter, pårørende og ansatte, noe som har vært utrolig nyttig for meg som samfunnsmedisiner og leder. Til dags dato har jeg aldri møtt en politiker som har påstått at jeg ikke kjenner hverdagen ute eller vet hvor skoen trykker.

- Blir du ikke sliten av å jobbe så mye?

- Nei, så langt har jeg ikke kjent på det, tvert imot! Jobben gir energi. Men jeg merker alderen ved at overskudd og humør er blitt mer avhengig av trening og tur med bikkja.

\section{Samhandling på mange plan}

Som ekspedisjonssjef i Samhandlingsavdelingen i Helsedepartementet hadde Tor Åm det administrative ansvaret for regjeringens arbeid med Samhandlingsreformen. Tidligere helseminister Bjarne Håkon Hanssen var inspirert av avtaleverk og tiltak mellom Trondheim kommune og Regionsykehuset i Trondheim (nå St. Olavs hospital), som Åm som kommuneoverlege hadde vært med på å utvikle. Den lokale samarbeidsavtalen så dagens lys i 1993 etter langvarige problemer spesielt knyttet til utskrivningsklare pasienter. Problemene toppet seg da Adresseavisen kunne fortelle om kvinnen som hadde ligget utskrivningsklar i over et år og fikk spørsmål fra Folkeregisteret om hun ønsket å endre sin faste adresse til sykehuset. 
- I Trondheim kommune forsto vi at om befolkningen skulle ha tillit til våre tjenester, måtte vi løse opp i denne problemstillingen. Jeg var med i Wisløff-utvalget i 2004-05, som resulterte i NOU 2005:3, «Fra stykkevis til helt - en sammenhengende helsetjeneste». Da Helsedepartementet skulle følge opp dette, ble jeg bedt om å delta i arbeidet.

Legevakt gir et fantastisk overblikk over hvordan velferdsstaten fungerer

- Samhandlingsreformen, har den vært en suksess?

- Mange påstår at den ble en døgnflue. Jeg er ikke enig i det. Samhandlingsreformen har medført store forbedringer med hensyn til pasientsikkerhet i overgangene mellom sykehus og kommunehelsetjeneste. Men vi har fortsatt mye å ta tak i og håper på flere virkemidler fra staten.

-Vi må innom koronakrisen. Hva har vi lært av den?

- Vi har blitt minnet på at vi i altfor liten grad tar advarsler alvorlig, og at verden kan endres veldig fort. Tunge fagmiljø hadde lenge sagt at verden er sårbar for en pandemi. Til tross for dette var vi dårlig forberedt på det som traff oss våren 2020. Samtidig har vi lært at vi kan takle slike kriser. Sykehusene Levanger og Namsos i Helse Nord-Trøndelag har på kort tid lagt planer for utstyr, ombygging og kompetansebygging for å ruste oss for det som kanskje kommer. Jeg er mektig imponert og stolt over å være en del av en organisasjon der medarbeidere har jobbet døgnet rundt med å forberede for og ta imot koronapasienter, samtidig som vi har forsøkt å opprettholde så normal drift som mulig.

\section{Å se seg tilbake}

Praten har vart lenge. Flyet til Trondheim går snart. Det er tid for å runde av, men det er to siste spørsmål jeg har lyst til å stille.

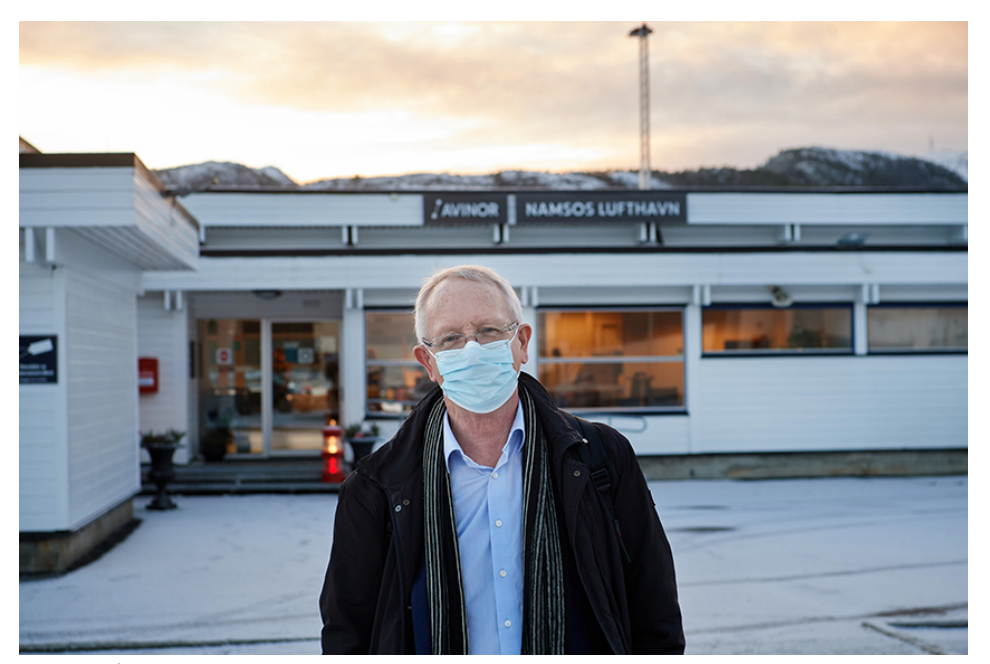

Foto: Bjørn Tore Ncess

- Når du ser tilbake på yrkeskarrieren, er det da noe du er spesielt glad for eller stolt av?

Han blar raskt raskt bakover i hukommelsen og lander på 2007.

- Den sommeren hadde Trondheim seks-sju overdosedødsfall blant veldig unge mennesker. Jeg så at vi måtte gjøre noe og inviterte til idédugnad. Representanter fra ambulansetjenesten sa at det føltes utrygt å forlate pasientene når de hadde gitt akutt hjelp etter overdoser. De ønsket seg noen å samarbeide med i slike situasjoner.

Som resultat av idedugnaden etablerte Trondheim kommune et overdose-/helseteam. Engasjerte og dyktige sykepleiere ble ansatt for å jobbe på gata, dele ut sprøyter og være tett på rusmiljøet. De fikk i oppgave å følge opp 113-utrykninger og har med det forebygget mange dødsfall.

- Dette har vært så vellykket at det fortsatt driftes over samme lest, forteller han stolt, og legger til at han bare var én av mange som fikk dette på plass. 
- Men er det noe du angrer på?

Nå blir det stille, dette spørsmålet var han ikke forberedt på.

- Nei, ikke noe jeg kommer på i farten, sier han med et smil.

- Jeg har alltid grepet de sjansene som har bydd seg og aldri angret på det.

Dagen etter intervjuet kommer det en mail der han utdyper:

- På turen hjem satt jeg og tenkte videre på hva jeg eventuelt angrer på. Det jeg burde ha nevnt i går, var at å være ansvarlig for eldreomsorg $\mathrm{i}$ en kommune er en uriaspost hvor det er langt mellom lyspunktene. Jeg har noen ganger litt for spøk sagt at jeg i mitt neste liv heller vil jobbe med tilbud til barn og unge i en positiv utvikling. Nå opplever jeg at å jobbe på sykehus også gir mye energi, fordi mange pasienter er fornøyd med god utredning og god behandling. Så kanskje jeg skal ønske å fortsette som sykehusdirektør også i mitt neste liv- om jeg får sjansen.

Publisert: 21. januar 2021. Tidsskr Nor Legeforen. DOI: 10.4045/tidsskr.20.1036

(C) Tidsskrift for Den norske legeforening 2020. Lastet ned fra tidsskriftet.no 